\title{
SYNTHESIS of Ag-DOPED ZnO NANOFIBERS USING ELECTROSPINNING METHOD and THEIR PHOTOCATALYTIC ACTIVITIES
}

\author{
1,2Ozlem ALTINTAS YILDIRIM \\ ${ }^{1}$ Selçuk University, Faculty of Engineering, Department of Metallurgical and Materials Engineering, Konya, \\ Turkey \\ ${ }^{2}$ Konya Technical University, Faculty of Engineering and Natural Sciences, Department of Metallurgical and \\ Materials Engineering, Konya, Turkey \\ ozlemaltintas@gmail.com
}

(Received/Geliş: 08.02.2018; Accepted in Revised Form/Kabul: 07.03.2018)

\begin{abstract}
Silver (Ag) doped zinc oxide ( $\mathrm{ZnO})$ nanofibers with 1 at. $\%$ and 3 at.\% Ag content were prepared using the electrospinning technique and their structural, morphological and photocatalytic properties were investigated. Pure $\mathrm{ZnO}$ nanofibers were also prepared with the same procedure for structure and property related comparison purposes. The photocatalytic activity of the Ag doped $\mathrm{ZnO}$ nanofibers were determined as a function of $\mathrm{Ag}$ content by exploring the degradation behavior of methylene blue under UV light irradiation. It was found that photocatalytic ability of fibers was improved with Ag addition and higher Ag incorporation resulted higher methylene blue degradation rate. For pure $\mathrm{ZnO}$ fibers, the degraded amount of dye was $52 \%$ of its initial amount after 270 min of UV irradiation time. For the same irridation time, $60 \%$ and $67 \%$ decomposition ratios of the dye molecules were achieved with the fibers containing 1 at.\% $\mathrm{Ag}$ and 3 at.\% $\mathrm{Ag}$, respectively. The origin of the improvement of photocatalytic activity in $\mathrm{Ag}$ doped $\mathrm{ZnO}$ nanofibers was attributed to the substitutional incorporation of $\mathrm{Ag}$ ions into $\mathrm{Zn}$ sites within the $\mathrm{ZnO}$ crystal. The substitutional incorporation has been proved with the positional shift of the XRD diffraction lines.
\end{abstract}

Key Words: Ag doping, Electrospinning method, Photocatalytic property, $\mathrm{ZnO}$ nanofibers.

\section{Elektro Eğirme Yöntemi Kullanılarak Ag Aşılanmış ZnO Nano Fiberlerin Sentezi ve Foto Katalitik} Aktivitelerinin İncelenmesi

ÖZ: \%1 ve \%3 gümüş (Ag) içeren $\mathrm{Ag}$ aşılanmış çinko oksit $(\mathrm{ZnO})$ nano fiberler elektro eğirme yöntemi kullanılarak hazırlanmış ve yapısal, şekilsel ve foto katalitik özellikleri incelenmiştir. Saf $\mathrm{ZnO}$ nano fiberler de yapı ve özelliklerin karşılaştırılması amacı ile aynı yöntemle sentezlenmişlerdir, Ag aşılanmış $\mathrm{ZnO}$ nano fiberlerin foto katalitik özellikleri UV ışığ altında metilen mavisini bozma eğiliminin Ag miktarına bağlı olarak değişiminin bir fonksiyonu olarak belirlenmiştir. Ag aşılama ile fiberlerin foto katalitik aktivitelerinin geliştiği ve yüksek miktarda Ag miktarının eklenmesi ile metilen mavisinin bozunum oranının daha iyi olduğu bulunmuştur. Saf $\mathrm{ZnO}$ fiberler ile 270 dakikalık UV 1şımasından sonra boyanın bozunum miktarının \%52 oranında olduğu tespit edilmiştir. Aynı 1şıma suresinde \%1 Ag içeren fiberlerde boya moleküllerinin bozunum oranı \%60 iken, \%3 Ag içeren fiberlerde bu oran \%77'dir. $\mathrm{Ag}$ aşılama ile $\mathrm{ZnO}$ fiberlerin foto katalitik aktivitelerinde gözlemlenen iyileşme $\mathrm{ZnO}$ kristal yapısında $\mathrm{Zn}$ bölgeleri içine Ag iyonlarının yer alan atom olarak geçmesi ile açıklanabilir. Yer alan atom pozisyonunda yerleşme XRD piklerinin pozisyonlarında meydana gelen kayma ile doğrulanmıştır.

Anahtar Kelimeler: Ag aşılama, Elektro eğirme yöntemi, Foto katalitik özellik, ZnO nano fiberler. 


\section{INTRODUCTION}

During the last few decades, water and air pollution have created a driving force for the fundamental and applied research in the waste stabilization and environmental remediation areas (Sharma and Lewis 1994). The control of the optical properties of semiconductor materials have increased the importance in the technological applications of the environmental remediation. In the literature, studies related with optical properties of II-VI type semiconductor nanomaterials are mainly focused on the CdSe and CdS nanoparticles containing hazardous elements to the environment (Costi et al., 2008; Yan et al., 2009). However, as an environmentally friendly semiconductor, zinc oxide (ZnO) nanostructures with wide band gap $(3.37 \mathrm{eV})$ and large exciton binding energy $(60 \mathrm{meV})$ show unique optical properties, providing that $\mathrm{ZnO}$ nanoparticles are in the foreground material in the technological applications in variety fields such as gas sensors, field emitters, solar cells and photocatalytic applications (Lee et al., 2016).

One of the important application area of $\mathrm{ZnO}$ nanostructures is the photocatalytic applications. In this application field, the aim is to destroy unwanted organisms in the air, water and various surfaces with a chemical reaction using a common and inexpensive energy source such as light energy (Serpone and Pelizzetti 1989). The working mechanism of photocatalytic devices is based on the principle of accelerating the photo reaction of a semiconductor material with wide band gap under solar energy. For the photocatalytic reactions, although solar energy is harmless and the most common source of the energy, UV radiation is found to be more effective to degrate dye molecules. The photocatalytic activities of semiconductor materials are classified according to their tendency to form electron-hole pairs under the photoluminescence. When semiconductor nanoparticles are exposed to UV radiation with more energy than their band-energy, they will form hole in the valence band and electrons in the conduction band (O'Neil et al., 1990). The photocatalytic reaction will occur when these electron-hole pairs reach the surface of the material. As a catalyst material, $\mathrm{ZnO}$ nanostructures have been observed to be highly effective in visible and near-infrared regions because they require high-energy UV radiation to act as catalysts. In addition, rapid recombination of the resulting electron-hole pairs is another limitting for $\mathrm{ZnO}$. Various methods have been tried to solve these problems, such as semiconductor junction (Chen et al. 2008), transition metal doping (Litter, 1999) and noble metal doping (Li et al. 2011). Among these techniques, it has been observed that the photocatalytic activity can be effectively improved with noble metal addition. It has been observed that the addition of palladium, gold and silver as an advanced metal addition enhances photocatalytic activity (Liqiang et al., 2004; Wu and Tseng 2006; Seery et al., 2007).

The development of the photocatalytic activities of $\mathrm{ZnO}$ nanoparticles by $\mathrm{Ag}$ doping has been particularly attractive (Yıldırım et al., 2013; Patil et al., 2016). It was reported that the surface modifications in terms of size and morphology of the Ag doped $\mathrm{ZnO}$ particles significantly affect the photocatalytic properties of the $\mathrm{ZnO}$ nanoparticles (Ylldirım et al., 2013). L. Wang reported that morphologically smooth $\mathrm{ZnO}$ nanoparticles exhibit better photocatalytic properties than according to a non-homogeneous morphology (Wang, L. et al., 2008). In addition, Y. Wang observed that the nano flower structure has better photocatalytic activity than rod structure (Wang, Y. et al., 2008). Because of the different working requirements in its applications, the synthesis of $\mathrm{Ag}$ doped $\mathrm{ZnO}$ nanostructures with well-controlled size and morphology have been also attracted a great attention (Wang et al., 2004). These special morphologies of Ag doped $\mathrm{ZnO}$ nanostructures such as nanorods (Hsu and Chang, 2014), nanofilms (Wang et al., 2006), nanoellipsoids (Kumar et al., 2015) and nanoparticles (Yildırım et al., 2013) have been synthesized using methods ranging from gas phase processes to solution routes.

Although $\mathrm{ZnO}$ nanoparticles in a few nanometers size scale have been reported a superior photocatalytic activity due to their large surface to volume ratios, in a practical photocatalytic applications, separation of these particles from the solution could be a problem. Furthermore, agglomeration of the particles in the catalyst solution is another common problem causing to reduce photocatalytic activity. For these aspects, nanofiber catalyst can be proper candidate because of their 
unique properties originated from well-defined geometry, ordered structure, flexibility of form, threedimensional open structure, large specific surface area, easy scale-up, and easily separation from the solution. The electrospining method is favorable to synthesize $\mathrm{Ag}$ doped $\mathrm{ZnO}$ fibers due to higher efficiency. In this study, it was aimed to synthesize $\mathrm{Ag}$ doped $\mathrm{ZnO}$ fibers via electrospinning technique and to determine effect of the $\mathrm{Ag}$ addition on the photocatalytic property of $\mathrm{ZnO}$ fibers. For this purpose, $\mathrm{ZnO}$ fibers were synthesized with different $\mathrm{Ag}$ content and in the studied dopant content range, the optimum amount of Ag required for the best photocatalytic property was determined.

\section{MATERIALS AND METHOD}

Zinc acetate dehydrate $\left(\mathrm{C}_{4} \mathrm{H}_{6} \mathrm{O}_{4} \mathrm{Zn} \cdot 2 \mathrm{H}_{2} \mathrm{O}, \% 99.5\right.$, Fluka), polyvinyl alcohol (PVA, $\left(\mathrm{C}_{2} \mathrm{H}_{4} \mathrm{O}\right) \mathrm{n}$, $\mathrm{MA}$ $\sim 55000$, Aldrich), silver acetate $\left(\mathrm{C}_{2} \mathrm{H}_{3} \mathrm{AgO}_{2}, \% 99.99\right.$, Aldrich), ethonol $\left(\mathrm{C}_{2} \mathrm{H}_{6} \mathrm{O}, \% 99\right.$, Merck) were used as raw materials for the production of $\mathrm{ZnO}$ and $\mathrm{Ag}$ doped $\mathrm{ZnO}$ fibers. All materials were of analytical grade and used without further purification.

\section{Production of Ag-Doped ZnO Nanofibers}

Synthesis of $\mathrm{ZnO}$ nanofibers was carried out by dissolving of $1.54 \mathrm{~g}$ PVA in $10 \mathrm{ml}$ distilled water and mixing of the solution at $70^{\circ} \mathrm{C}$ for 4 hours using a magnetic stirrer. $1 \mathrm{~g}$ of zinc acetate dihydrate was added to PVA solution and mixing was continued for 1 hour to obtain homogeneous solution. The zinc acetate dehydrate solution was then added drop by drop to the PVA solution. At the end of the dripping process, final solution was stirred further 2 hours to achieve complete homogeneity. Then, the solution was inserted into a disposable sterile syringe having a needle pin inner diameter of $0.8 \mathrm{~mm}$ and connected to an automatic syringe pump to spray at a $0.3 \mathrm{~mL}$ per hour rate. Aluminum foil was used to collect the fibers. During production of the fibers, the distance between the syringe tip and foil was set to $15 \mathrm{~cm}$ and applied voltage was set to $15 \mathrm{kV}$ in the electrospining unit.

In order to fabricate $\mathrm{Ag}$ doped $\mathrm{ZnO}$ nanofibers, silver acetate was added in the PVA-ZnO stock solution. For this purpose, silver salt was added to the stock solution at amounts equivalent to 1 and 3 at.\% Ag ion. Subsequently, they were mixed at room temperature with a magnetic stirrer for 1.5 hours in order to homogeneously distribute the ions in the solution. The silver containing solution was added to the main solution and stirred at room temperature for approximately 1 day. After mixing, the stock solution containing Ag was taken into a single-use sterile syringe and spraying was performed using the same parameters as the production of $\mathrm{ZnO}$ fibers with an automatic syringe pump.

After the end of the electrospinning process of the all $\mathrm{ZnO}$ and $\mathrm{Ag}$ doped $\mathrm{ZnO}$ fibers, aluminum foils were put into a vacuum dryer at $70{ }^{\circ} \mathrm{C}$ for 8 hours. In order to remove PVA and organic pollution from the $\mathrm{ZnO}$ structure and to increase the crystallinity of the $\mathrm{ZnO}$ fiber structure, the fibers were subjected to a heat treatment at $400{ }^{\circ} \mathrm{C}$ for 5 hours.

\section{Characterization}

The phase distributions of the nanofibers were determined by X-ray diffraction (XRD). The size and morphology of the nanofibers were investigated by scanning electron microscopy (SEM). For the measurement of the photocatalytic activities of $\mathrm{ZnO}$ fibers, the degradation rate of methylene blue (MB) dye under UV irradiation were determined by UV-Vis spectrometry. Photocatalytic measurements were firstly carried out in a dark region. Then, $100 \mathrm{~W}$ UV lamp was used to observe degradation of the organic dye under UV light. To investigate the photocatalytic ability, $50 \mathrm{mg}$ of MB was dissolved in 50 $\mathrm{mL}$ of deionized water to prepare a stock solution. In order to measure the photocatalytic activity of the $\mathrm{ZnO}$ nanofibers, $50 \mathrm{mg}$ fiber was added to the dye solution and the solution was then subjected to continuous stirring in a dark box. In order to measure the degree of degradation in the dark media, the absorption spectrum between 300-600 nm was examined by UV-Vis spectroscopy. After the exposure 
with the $100 \mathrm{~W}$ of UV light, measurements were periodically carried out each $0.5 \mathrm{~h}$ by examining degradation of the $4 \mathrm{~mL}$ of the solution. Photocatalytic activities of the 1 and 3. at.\% $\mathrm{Ag}$ doped $\mathrm{ZnO}$ fibers were also investigated with the same procedure.

\section{RESULTS and DISCUSSIONS}

Figure 1 (a) shows $\mathrm{x}$-ray diffractograms of $\mathrm{ZnO}$ and $\mathrm{Ag}$-doped $\mathrm{ZnO}$ fibers synthesized via electrospinning technique. According to the $\mathrm{X}$-ray diffractograms, fibers are highly crystalline $\mathrm{ZnO}$ with the hexagonal wurtzite structure (JCPDS card number: 36-1451). No other crystalline phases were detected from the $\mathrm{ZnO}$ fibers. Peak intensities are in agreement with standard peak intensities in the JCPDS card data. For 1 and 3 at. $\%$ Ag addition, low-intensity peaks located at $2 \theta=38.37^{\circ}$ and $46.40^{\circ}$ were observed. These diffraction lines corresponds to the metallic silvers (Subhan et al. 2014). The intensity of these metallic Ag peaks increases with an increase in the dopant silver content.
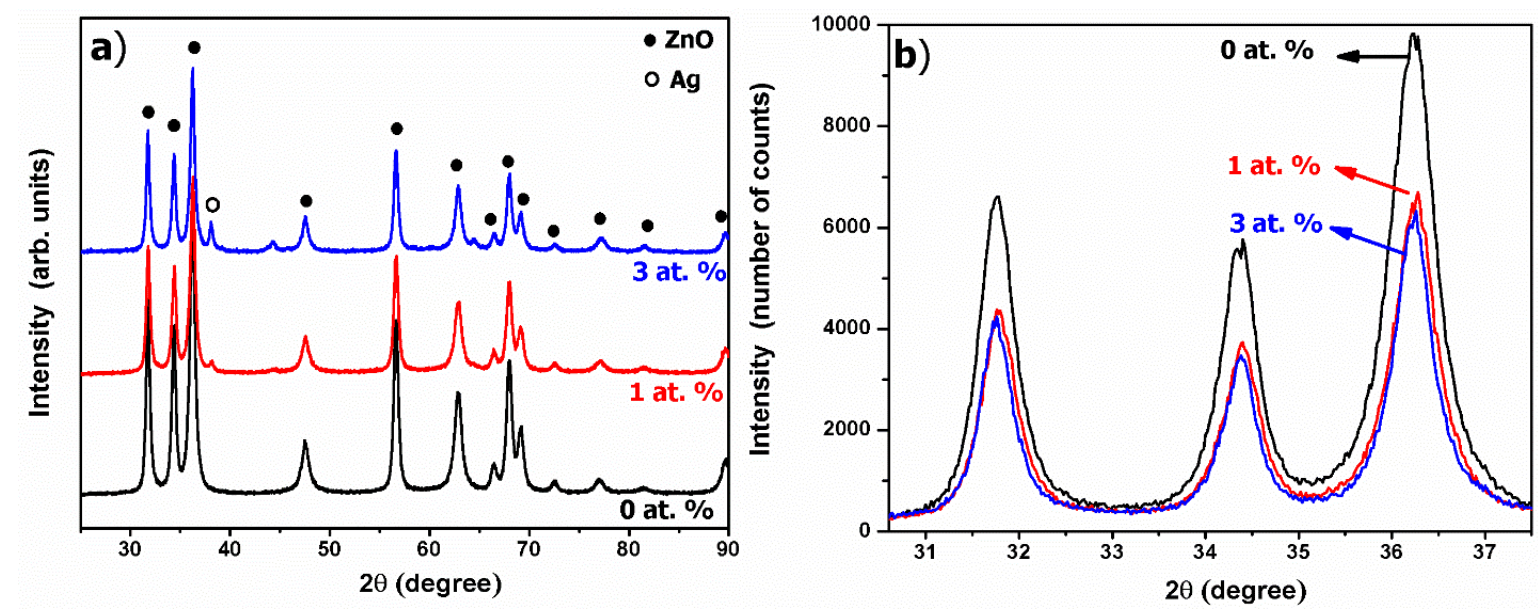

Figure 1. a) XRD diffractogram and b) enlarged XRD diffractogram between $2 \theta=30.5-37.5^{\circ}$ of $\mathrm{ZnO}$, $1 \%$ and 3\% Ag-doped $\mathrm{ZnO}$ nanofibers

The peak intensities and positions of $\mathrm{ZnO}$ diffractions were examined to investigate the effect of the $\mathrm{Ag}$ addition on the crystal structure of $\mathrm{ZnO}$ fibers. Figure 1 (b) shows the enlarged XRD diagrams between $2 \theta=31.5-37.5^{\circ}$ region. It was observed that 1 at. $\% \mathrm{Ag}$ addition considerably decrease the peak intensity of $\mathrm{ZnO}$ but in 3at.\% $\mathrm{Ag}$ doped $\mathrm{ZnO}$ fibers, $\mathrm{Ag}$ ions have less effect on the peak intensity. According to peak intensities, Ag addition diminished the crystallinity of $\mathrm{ZnO}$ fibers. The crystal structure of $\mathrm{ZnO}$ is composed of a zinc rich catalytic active top surface and an oxygen rich catalytic inert bottom surface. These two surfaces are also different in terms of energy. This difference ensures that $\mathrm{ZnO}$ has a polar structure. With the effect of this polarity, the particles in the solution medium are willing to enlarge low energy surface areas. The chemical structures present in the synthesis medium allow the particles to grow in the desired direction as a result of interaction with the $\mathrm{ZnO}$ core structure (Kolodziejczak-Radzimska and Jesionowski 2014). The formation of a second phase with Ag addition prevented the growth of $\mathrm{ZnO}$ crystals through the preferential growth direction. Due to this reason, XRD peak intensity and crystallite of $\mathrm{ZnO}$ decrease with Ag addition.

Figure 1 (b) also shows a slight shift in the peak positions of Ag-doped $\mathrm{ZnO}$ fibers. The $2 \theta$ values as a function of the $\mathrm{Ag}$ content are listed in Table 1. For pure $\mathrm{ZnO}$ fibers, the highest intense peak of hexagonal wurtzite structure appeared at $2 \theta=36.30^{\circ}$, however, the positions change to $2 \theta=36.28^{\circ}$ and $2 \theta=36.25^{\circ}$ for $1 \%$ and $3 \% \mathrm{Ag}$ doped $\mathrm{ZnO}$ fibers, respectively. This peak shift caused by Ag addition shows some of the $\mathrm{Ag}$ ions are substitutionally incorporated into $\mathrm{ZnO}$ crystal structure (Yildirım et al. 2013). Substitutional incorporation of $\mathrm{Ag}$ ions can be also proved from the lattice parameters of $\mathrm{ZnO}$. The c-axis lattice constant calculated from the (0002) plane are also listed in the Table I. As observed in 
Table I, lattice parameters indicate an enlargement of the lattice from 5.175 to $5.194 \AA$ as the $\mathrm{Ag}$ content increased from 0 to 3 at.\% because of bigger ionic size of $\mathrm{Ag}$ than that of the $\mathrm{Zn}\left(\mathrm{Ag}^{+}: 1.26 \AA\right.$ and $\mathrm{Zn}^{2+}$ : $0.74 \AA)$. According to peak shift in the XRD results and lattice parameter change, the Ag ions are substitutionally incorporated into the $\mathrm{ZnO}$ crystal by sitting in the $\mathrm{Zn}^{2+}$ sites.

Table 1. (002) peak position and lattice parameters for the undoped $\mathrm{ZnO}$ and $\mathrm{Ag}$-doped $\mathrm{ZnO}$ fibers with different Ag contents

\begin{tabular}{|c|cc|}
\hline $\begin{array}{c}\text { Ag:Zn ratio } \\
\text { (at.\%) }\end{array}$ & $\begin{array}{c}\text { (002) Peak Position } \\
\text { (degree of 20) }\end{array}$ & $\begin{array}{c}\text { Lattice } \\
\text { Parameter (c, } \mathbf{A})\end{array}$ \\
\hline $\mathbf{0}$ & 36.30 & 5.175 \\
$\mathbf{1}$ & 34.28 & 5.178 \\
$\mathbf{3}$ & 34.25 & 5.194 \\
\hline
\end{tabular}

Figure 2 shows low and high magnification SEM micrographs of as-prepared $\mathrm{ZnO}$ and 1 at.\% and 3 at.\% $\mathrm{Ag}$ doped $\mathrm{ZnO}$ fibers.As can be seen from the images, fibers with a smooth surface are approximately $40 \mu \mathrm{m}$ in length and $400 \mathrm{~nm}$ in diameter. The addition of Ag did not cause a significant change in the morphology of the as-prepared fibers.

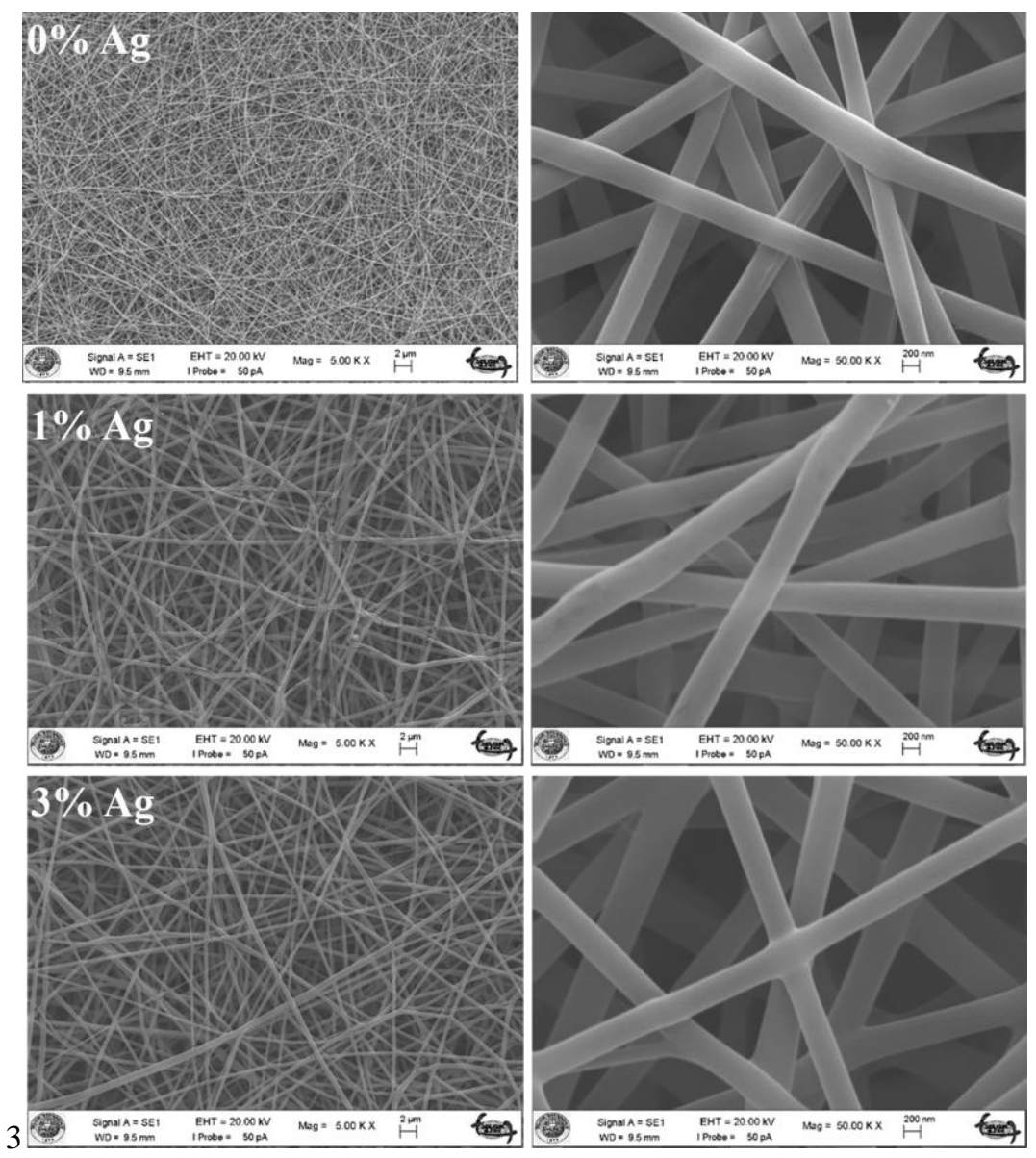

Figure 2. Low and high magnification SEM images of as-prepared $\mathrm{ZnO}, 1$ at. $\%$ and 3 at. $\% \mathrm{Ag}$-doped $\mathrm{ZnO}$ fibers.

Figure 3 shows low and high magnification SEM images of $\mathrm{ZnO}, 1 \%$ and $3 \%$ Ag-doped $\mathrm{ZnO}$ nanofibers obtained after heat treatment at $400{ }^{\circ} \mathrm{C}$ for 5 hours. With the removal of the polymer by the 
effect of heat treatment of the fibers, it can be seen that the diameters of the fibers reduce to nearly 80 $\mathrm{nm}$. After the heat treatment of the fibers, it can be also seen that fibers are formed by the particles which are $30 \mathrm{~nm}$ in diameter.
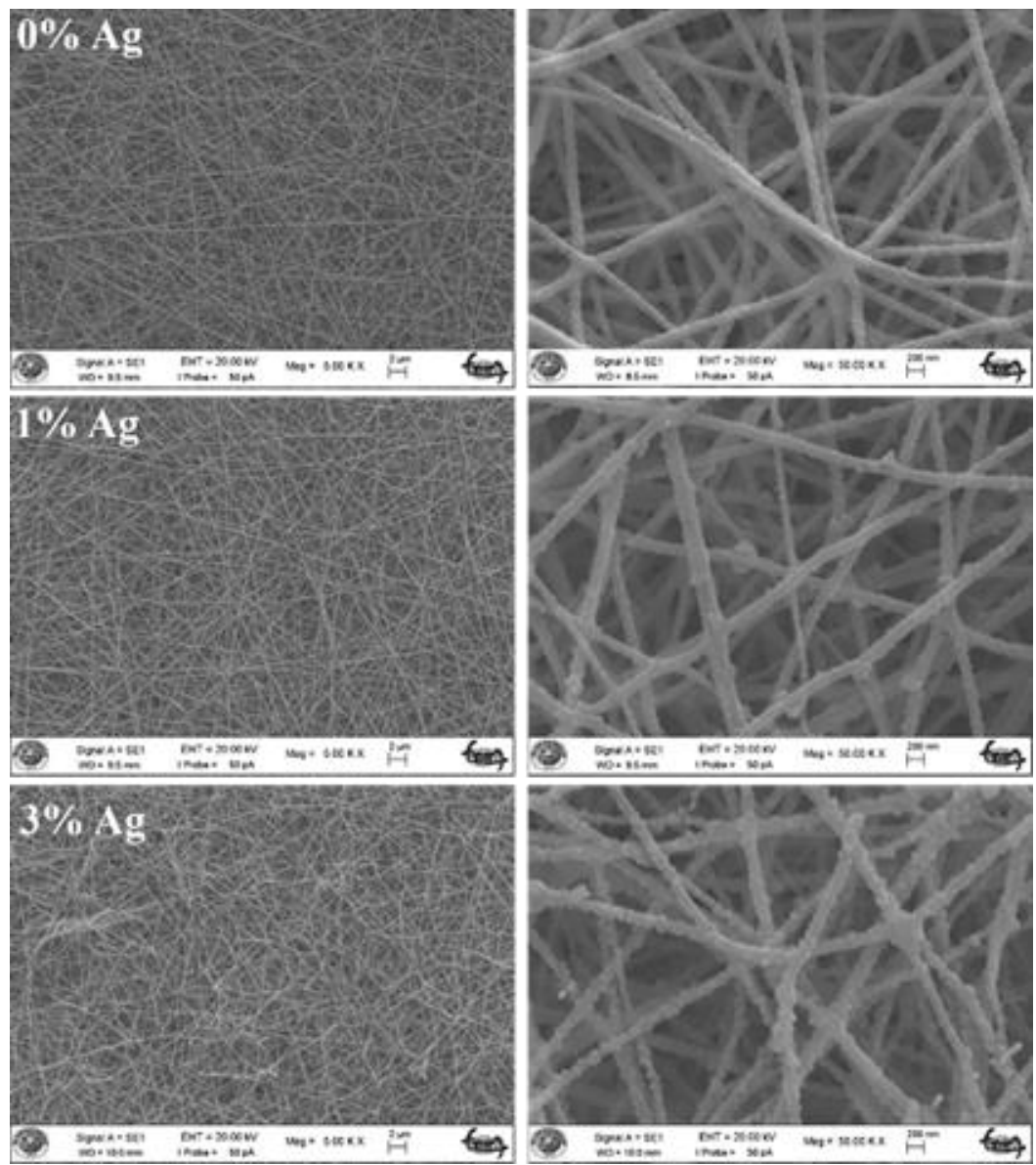

Figure 3. Low and high magnification SEM images of $\mathrm{ZnO}, 1$ at.\% and 3 at.\% Ag-doped $\mathrm{ZnO}$ nanofibers heat treated at $400{ }^{\circ} \mathrm{C}$ for 5 hours.

Photocatalytic activities of the nanofiber structures were investigated by the degradation profile of methylene blue under UV light. Figure 4 shows the degradation profile of all $\mathrm{ZnO}$ nanofibers. For the comparison purpose, degradation profile of the methylene blue solution without catalyst was also exposed to the UV-light under the same experimental conditions and showed a trace of change with respect to time. A diagram of the reaction of the methylene blue under the influence of light is shown in the Figure 4. It was observed that the methylene blue solution exposed to UV light for 4 hours underwent very little decomposition.

The maximum absorption band at $664 \mathrm{~nm}$ was used to degrade the methylene blue. As can be seen from the Figure 4, $\mathrm{ZnO}$ began to deteriorate from the 30 minutes and it was observed that the amount of deterioration increased with time due to the effect of UV light. The nanofibers added at 1 and 3 at.\% Ag were found to have more efficient for methylene blue dye degradation than that of the bare $\mathrm{ZnO}$ fibers. The methylene blue decay according to Figure 4 increases over time in all fiber structures. This degradation in the methylene blue shows the effect of addition of $\mathrm{Ag}$ on the photocatalytic properties of $\mathrm{ZnO}$ (Chen et al., 2008). 

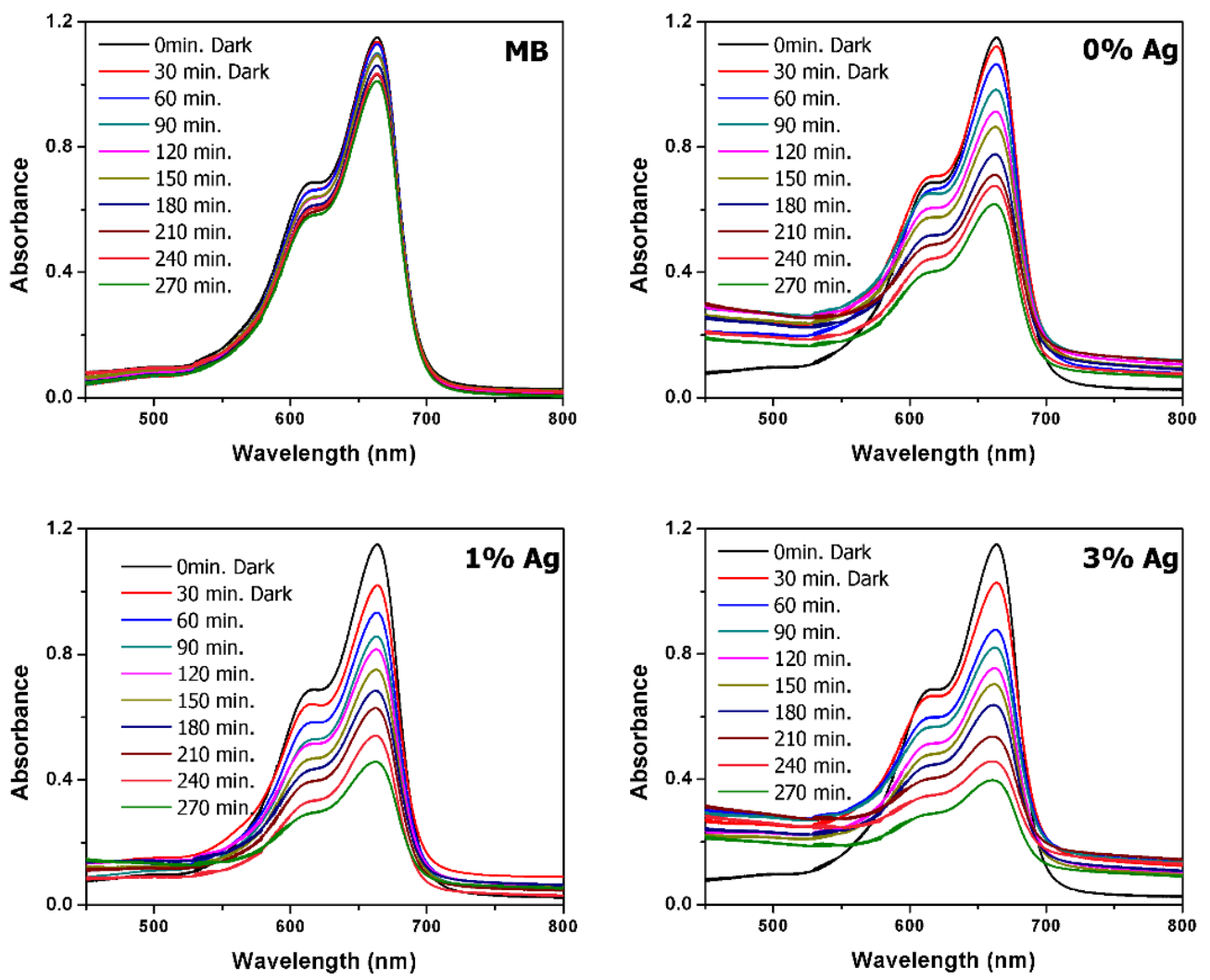

Figure 4. Real-time UV-vis absorption spectra of the photodegradation of methylene blue solutions containing the undoped and 1 at. $\%$ and 3 at.\% Ag-doped $\mathrm{ZnO}$ nanofibers.

Figure 5 exhibits the UV-light degradation of the dye molecules. After the 270 minutes UV irradiation, approximately 70\% decomposition was observed in dye molecules without catalyst addition. For the same irradiation time, $\mathrm{ZnO}$ fiber catalyst addition to methylene blue solution resulted in an exponentially decrease with respect to time and $48 \%$ decomposition was achieved. According to Figure 5, Ag addition increases the dye decomposition. 60\% degradation rate was observed with $1 \%$ Ag doped $\mathrm{ZnO}$ nanofiber. Furthermore, with an increase in the $\mathrm{Ag}$ dopant amount to 3 at.\%, degratation rate further increased to $67 \%$. Therefore, it has been observed that Ag addition improves the photocatalytic activities of $\mathrm{ZnO}$ nanofibers. This increase can be attributed to the change in the electronic structure of the $\mathrm{ZnO}$ by the silver ions sitting into $\mathrm{Zn}$ site of the crystal. The photocatalytic activity of semiconductor materials can usually be improved by providing the separation of excited electron-hole pairs (Liu et al. 2011). By employing substitutional incorporation of Ag ions into ZnO crystal structure, the photoexcited electron-hole pairs could be efficiency separated by an extra inner field. Based on the above experimental results, the improved photocatalytic efficiency could be due to substitutionally sitting of Ag ions into $\mathrm{ZnO}$ crystal. 


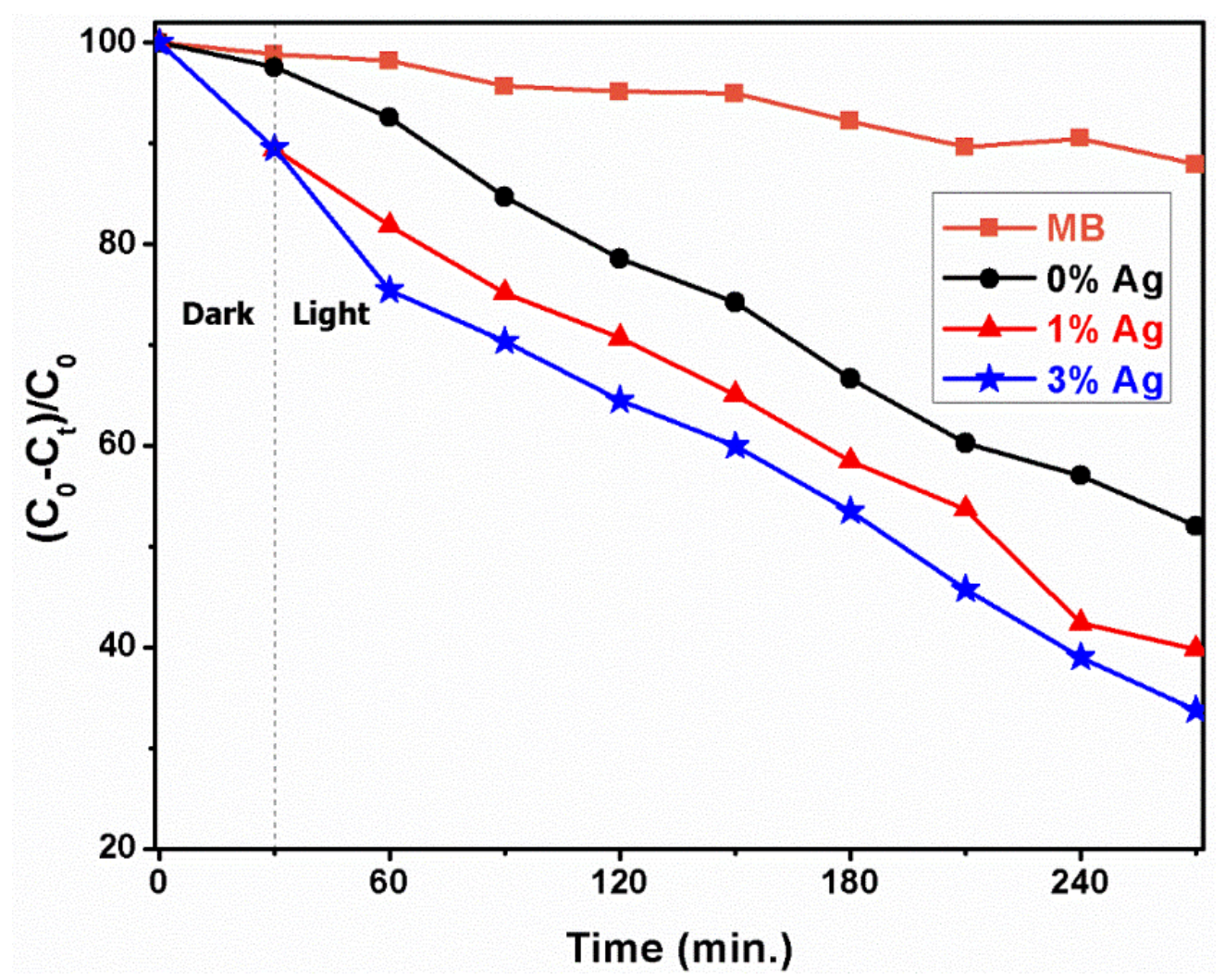

Figure 5. Time-dependent degradation profiles of $\mathrm{ZnO}$ and 1 at.\% and 3 at.\% Ag-doped $\mathrm{ZnO}$ nanofibers

\section{CONCLUSIONS}

In this study, $\mathrm{Ag}$ added $\mathrm{ZnO}$ nanofibers with approximately $40 \mu \mathrm{m}$ in length and $80 \mathrm{~nm}$ in diameter were fabricated by the electrospinning technique. The effects of the Ag addition on the structural, morphological and photocatalytic abilities of the $\mathrm{ZnO}$ nanofibers were investigated. According to XRD results, the addition of $\mathrm{Ag}$ to the $\mathrm{ZnO}$ crystal structure led to a shift in diffraction line position and a decrease in the peak intensities of the $\mathrm{ZnO}$ peaks. This shift in the peak positions indicates that the added $\mathrm{Ag}$ ions are substitutionally incorporated into the $\mathrm{ZnO}$ crystal structure. In addition, some of the added Ag ions has formed a separate phase as metallic Ag. The photocatalytic properties of the produced fibers were investigated by examining methylene blue dye degradation under UV light irradiation. It was found that the photocatalytic properties of $\mathrm{ZnO}$ nanofibers showing $48 \%$ degradation as a result of exposure to 270 minutes ofUV irradiation were improved with 1 and 3 at. $\%$ Ag addition to $60 \%$ and $67 \%$ degradation rates, respectively. These results show that $\mathrm{Ag}$ addition to $\mathrm{ZnO}$ fiber structure gives an opportunity to use nanofibers in the large-scale utilization of photocatalysts using UV light to overcome organic and/or water pollution.

\section{ACKNOWLEDGEMENT}

This study was carried out within the scope of project number 16401052 supported by Selcuk University Scientific Research Projects (BAP). We thank Selçuk University BAP for their financial support. 


\section{REFERENCES}

Chen, S., Zhao, W., Liu, W., Zhang, S., 2008, "Preparation, Characterization and Activity Evaluation of p-n Junction Photocatalyst p-ZnO/n-TiO 2", Applied Surface Science, Vol. 255, No. 5, pp. 24782484.

Costi, R., Saunders, A. E., Elmalem, E., Salant A., Banin, U., 2008, "Visible Light-induced Charge Retention and Photocatalysis with Hybrid CdSe- Au Nanodumbbells", Nano Letters, Vol. 8, No. 2, pp. 637-641.

Hsu, M.-H., Chang, C.-J., 2014, "Ag-doped ZnO Nanorods Coated Metal Wire Meshes as Hierarchical Photocatalysts with High Visible-Light Driven Photoactivity and Photostability", Journal of Hazardous Materials, Vol. 278, No. 1, pp. 444-453.

Kolodziejczak-Radzimska, A., Jesionowski, T., 2014, "Zinc Oxide-From Synthesis to Application: A Review", Materials, Vol. 7, No. 4, pp. 2833-2881.

Kumar, R., Rana, D., Umar, A., Sharma, P., Chauhan, S., Chauhan, M. S., 2015, "Ag-doped ZnO Nanoellipsoids: Potential Scaffold for Photocatalytic and Sensing Applications", Talanta, Vol. 137, No. 1, pp. 204-213.

Lee, K., M., Lai, C. W., Ngai, K. S., Juan, J. C., 2016, "Recent Developments of Zinc Oxide based Photocatalyst in Water Treatment Technology: a Review", Water Research, Vol. 88, No. 1, pp. 428-448.

Li, P., Wei Z., Wu, T., Peng, Q., Li, Y., 2011, "Au-ZnO Hybrid Nanopyramids and Their Photocatalytic Properties", Journal of the American Chemical Society, Vol. 133, No. 15, pp. 5660-5663.

Liqiang, J., Baiqi, W., Baifu, X., Shudan, L., Keying, S., Weimin, C., Honggang, F., 2004, "Investigations on the Surface Modification of ZnO Nanoparticle Photocatalyst by Depositing Pd", Journal of Solid State Chemistry, Vol. 177, No. 11, pp. 4221-4227.

Litter, M. I., 1999, "Heterogeneous Photocatalysis: Transition Metal Ions in Photocatalytic Systems", Applied Catalysis B: Environmental, Vol. 23, No. 2, pp. 89-114.

Liu, B., Nakata, K., Zhao, X., Ochiai, T., Murakami, T., Fujishima, A., 2011, "Theoretical Kinetic Analysis of Heterogeneous Photocatalysis: the Effects of Surface Trapping and Bulk Recombination Through Defects", The Journal of Physical Chemistry C, Vol. 115, No. 32, pp. 16037-16042.

O'Neil, M., Marohn, J., McLendon, G., 1990, "Dynamics of Electron-Hole Pair Recombination in Semiconductor Clusters", The Journal of Physical Chemistry, Vol. 94, No. 10, pp. 4356-4363.

Patil, S. S., Mali, M. G., Tamboli, M. S., Patil, D. R., Kulkarni, M. V., Yoon, H., Kim, H., Al-Deyab, S. S., Yoon, S. S., Kolekar, S. S., 2016, "Green Approach for Hierarchical Nanostructured Ag-ZnO and Their Photocatalytic Performance under Sunlight", Catalysis Today, Vol. 260, No. 1, pp. 126134.

Seery, M. K., George, R., Floris, P., Pillai, S. C., 2007, "Silver Doped Titanium Dioxide Nanomaterials for Enhanced Visible Light Photocatalysis", Journal of Photochemistry and Photobiology A: Chemistry, Vol. 189, No. 2-3, pp. 258-263.

Serpone, N., Pelizzetti, E., 1989, Photocatalysis: fundamentals and applications

Sharma, H. D., Lewis, S. P., 1994, Waste Containment Systems, Waste Stabilization, and Landfills: Design and Evaluation, John Wiley \& Sons.

Subhan, M. A., Awal, M., Ahmed, T., Younus, M., 2014, "Photocatalytic and Antibacterial Activities of $\mathrm{Ag} / \mathrm{ZnO}$ Nanocomposities Fabricated by Co-Precipitation Method", Acta Metallurgica Sinica (English Letters), Vol. 27, No. 2, pp. 223-232.

Wang, L., Chang, L., Zhao, B., Yuan, Z., Shao, G., Zheng, W., 2008, "Systematic Investigation on Morphologies, Forming Mechanism, Photocatalytic and Photoluminescent Properties of $\mathrm{ZnO}$ Nanostructures Constructed in Ionic Liquids", Inorganic Chemistry, Vol. 47, No. 5, pp. 14431452. 
Wang, R., Xin, J. H., Yang, Y., Liu, H., Xu, L., Hu, J., 2004, "The Characteristics and Photocatalytic Activities of Silver Doped ZnO Nanocrystallites", Applied Surface Science, Vol. 227, No. 1, pp. 312-317.

Wang, X., Song, C., Geng, K., Zeng, F., Pan, F., 2006, "Luminescence and Raman Scattering Properties of Ag-doped ZnO films", Journal of Physics D: Applied Physics, Vol. 39, No. 23, pp. 4992.

Wang, Y., Li, X., Wang, N., Quan, X., Chen, Y., 2008, "Controllable Synthesis of ZnO Nanoflowers and Their Morphology-Dependent Photocatalytic activities", Separation and Purification Technology, Vol. 62, No. 3, pp. 727-732.

Wu, J.-J., Tseng, C.-H., 2006, "Photocatalytic Properties of nc-Au/ZnO Nanorod Composites", Applied Catalysis B: Environmental, Vol. 66, No. 1-2, pp. 51-57.

Yan, H., Yang, J., Ma, G., Wu, G., Zong, X., Lei, Z., Shi, J., Li, C., 2009, "Visible-light-driven Hydrogen Production with Extremely High Quantum Efficiency on Pt-PdS/CdS Photocatalyst", Journal of Catalysis, Vol. 266, No. 2, pp. 165-168.

Yıldırım, O.A., Unalan, H. E., Durucan, C., 2013, "Highly Efficient Room Temperature Synthesis of Silver-Doped Zinc Oxide (ZnO: Ag) Nanoparticles: Structural, Optical, and Photocatalytic Properties", Journal of the American Ceramic Society, Vol. 96, No. 3, pp. 766-773. 